\title{
PRESENTING THE MARKET VALUE MODEL OF PROFESSIONAL FOOTBALL PLAYERS IN IRAN: A CONSTRUCTIONIST APPROACH OF GROUNDED THEORY
}

\author{
Rasool Nazari ${ }^{1 i}$, \\ Saeid Mahmoodizad Azari² \\ ${ }^{1}$ Associate Professor, \\ Sport Management, \\ Isfahan (Khorasgan) Branch, \\ Islamic Azad University, \\ Isfahan, Iran \\ ${ }^{2} \mathrm{PhD}$, Sport Management, \\ Isfahan (Khorasgan) Branch, \\ Islamic Azad University, \\ Isfahan, Iran
}

\begin{abstract}
:
The present study intends to design a value model for professional players in the Iranian Football. The present study has been done with exploratory nature and with the aim of expanding the existing knowledge and understanding about capabilities in the field of football in order to present the model from the findings derived from the code, an attempt has been made to use a structural approach of data-based theory of the Charms Foundation. Three overlapping processes in the structural analysis of data-based theory are: Primary, centralized, and theoretical coding. In the implementation of the research, data collection and analysis were done consciously simultaneously, and the initial data were collected in order to form the process of continuous data collection. Participants included people familiar with the Iranian professional football, who were purposefully selected. Based on the findings in this stage of the research, out of about 220 sentences implemented from the interviews, after removing duplicate and unrelated items, 109 primary codes were identified and marked by the researcher in the first stage. In centralized coding, it was divided into 7 categories. Finally, at the highest level of reduction or brevity, the categories of construction were reduced to three general categories of equity, requirements and market value of a player, which in the most desirable way, integrated the concepts created in the research into three levels. The final price or value of a football player in the Iranian Premier League in the transfer market is determined based on the player's special values.
\end{abstract}

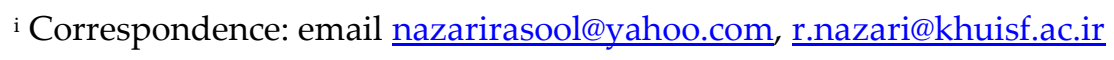


Keywords: value, player, football, model, data-based theory

\section{Introduction}

Football is a sport that, with its expansion, is now one of the most popular sports in the world (Bondarik, 2020; 1-17). In Iran, football is one of the most popular sports and, in fact, is part of society and is becoming more important day by day. For this reason, it is necessary for officials and managers of sports organizations to pay much attention to this field (Sadeghi \& et al., 2009; 27-41). Today, football has become a lucrative industry that has always been in the spotlight of the media, businesses and other industry owners due to the great interest of the people in it. Clubs that focus on football need to generate revenue to be able to cover all the necessary and unavoidable costs of this popular sport. Major and general costs of football teams include player salaries and bonuses, transfer costs and transfer of players to other clubs, manpower management costs, creation and maintenance of sports facilities, travel costs, insurance, taxes and administrative and service costs (Amir \& Lione, 2005; 549-586).

However, the main costs associated with football clubs can be considered the billion-dollar trade of player contracts in the transfer season. Government participation, public relations, developing the capacity and national culture seem to have been significant strategic factors for the commercialization of football sport in Kenya, and suggests that the management of football organizations in Kenya should deliberately address a variety of strategic factors, including government participation and relations, and adopt public capacity and national culture to ensure commercialization of the football sector in Kenya (Origi, 2019; 1-19). From a managerial point of view, one of the most important decisions that team managers make is the decision regarding player transfers, hence the issue of player valuation, especially the determination of transfer costs and market values in a scientific and effective way which is one of the main concerns of football club managers around the world. It is recommended to the managers of the Football Federation in order to excel in the national brand of Iranian football to consider the criteria, including revenue generation through the sale of academy players. In this regard, professional football earns a lot of money due to their high popularity; they are no longer just a club, but companies with shareholders and managers, sales, profits and customers instead of fans (Nazari \& et al, 2019; 95-109).

The sports industry has the characteristics of increasing domestic demand, increasing employment and creating new points of economic and business growth $(\mathrm{Xu} \&$ Yang, 2019; 5399). With the continuous expansion of the sports industry, the effect of the promotion of the sports industry on economic development has gradually emerged $(\mathrm{Xu}$ \& Yang, 2020; 813).

This industry, by having a stimulating factor such as major sports competitions, has provided the possibility of benefiting from advertising opportunities in the media, which has created the necessary platform for interaction between industry, trade and sports. Professional sports in the meaning of exercise to make money, has been changed 
into the main part of the sports industry (Rezaei, 2017; 65-86). Professional athletes receive high salaries, those rights will be provided usually through ticket sales, TV broadcasting rights and the companies' support (Rezaei Sofi \& Shabani, 2017; 107118).The pillars of professional sports are athletes, coaches and clubs, and the financial resources of professional sports include ticket sales and tournament advertising, public donations, player transfers, TV broadcasting rights, membership fees, government grants, sponsors and tax exemptions ( Arab Narimani, Sajadi \& Khabiri, 2018; 17-37).

Deloitte economic organization in 2016, has predicted the Europe's football industry turnover in the 2014 - 2015 season over 22 billion euros and 25 billion euros for 2016 - 2017 season; so, football is now the owner of all the necessary factors for being an "Industry". Football is a growing business and generates significant economic interest among a wide variety of consumers and stakeholders (Yiapanas, 2020; 222-241).

Global marketing strategies have analyzed Bayern Munich's in terms of sporting achievements, financial performance and the number of global fans. In addition, the club's past steps in attracting domestic and foreign fans along with revenue-generating tools for clubs and interactions between them and sports teams can be effective in increasing brand equity (Baena, 2016; 1-15). Given that very large sums of money are spent annually in the world football industry for the transfer of players who are the most valuable financial and capital resources of a club, so the main issue in this regard is the ability to predict value of each player in the transfer market using valuation techniques and models that will be possible based on the collection of data and information from various resources (Izadyar, Memari \& Mosavi, 2015; 25-40).

One of these resources is the German transfer market website, which controls the judgment of the value of players in the transfer market, and based on the same information posted on this website, the most detailed information about important players and key players are recorded and on the other hand benefit from the point of view of experts and evaluate their value based on the analysis of this data in the market, given that the material value of professional football players for clubs is very economic. It seems that predicting the value of players in the market as a real asset can be effective in the entire football industry and global investment for all people in the sport. Hence, the price is a very vital and influential element in predicting the market value of football players. Every year a lot of liquidity and money is exchanged in the transfer cycle of players in different leagues of the world, especially European leagues, and for various reasons, obtaining a proper economic assessment for the transfer of players during the year is very important and valuable (He, 2015; 85).

Regarding the value of soccer player transfers, Chan (2014) examined nine factors that play a vital role in the pricing of soccer players. He stated that one of the most important elements is the age of the players. Older players between the ages of 30 and 35 do not have a high transfer value due to how they perform and their quality and the fact that they are reaching the end of their careers. Due to the strong dependence of Iranian sports clubs, especially clubs that are only active in football, such as Sepahan, Zobahan, Saipa, Foolad Khuzestan, Esteghlal, Perspolis to government budgets or industrial 
organizations, cost management and less financial management in these clubs are considered in line with the balance of budgets related to the transfer market, and therefore less attention is paid to generating revenue resources (Bagheri \& et al, 2011; 5065).

The globalization of sports has begun since the 1990s, and this necessity has changed the role of sports in all societies, thus creating many revenue-generating opportunities for individuals, institutions and the media from the sports industry. In recent decades, several sports clubs have been active in the structure of sports in Iran, most of which are supported by government agencies or funded by these organizations and organs and some by the private sector, and all costs related to the income of these clubs, which also includes the transfer costs of football players, is provided from the same places (Izadyar, Memari \& Mosavi, 2015; 25-40).

Due to the strong dependence of Iranian sports clubs, especially clubs that operate only in football on government budgets or industrial organizations, cost management and less financial management in these clubs is considered in order to balance budgets related to the transfer market, and therefore less attention is paid to creating resources of income(Bagheri \& et al, 2011; 50-65).

Given that sports clubs need significant financial resources to meet their essential costs in the transfer market, the purchase of required players and the power to predict what role the players in the club's shopping list will play in the transfer market of every season of the Iranian Premier League matches, and the price of each of them is one of the best economic variables affecting the demand in the transfer market, it is clear that their predicted price and value is somehow the most critical element in marketing effective factors (Sadeghi, 2009; 27-41). Given the importance of the amounts paid to buy players and the role of these resources in achieving sports and commercial goals for sports clubs, determining and predicting the value of players for sports clubs, especially in football, is a very important issue. Football players are the most important and most expensive assets of sports clubs and in related markets, they are paid large sums of money, so it is necessary to identify the factors that predict the value of players in the transfer market and choose a procedure appropriate to the current situation. Predicting the valuation of football players seems to be very necessary and important, and therefore recognizing the predictors that can affect the rate and valuation of players due to the globalization of football economics and the generality of football in Iran, it is observed that the economic issues and revenue generation of football have been hotly debated in many newspapers, radio and television, and scientific meetings. In the meantime, it is important to note that due to the nascent professional football industry in Iran, the economic development of the football industry is in dire need of regular and organized scientific research. By conducting such research, suggestions can be made to governmental and nongovernmental policy makers, so that they can take fundamental steps towards the economic development of Iran's football industry through research-based decisions. On the other hand, one of the effective factors in football is the increasing growth of the phenomenon of brokerage in Iranian football, which can be boldly said that its growth 
rate has exceeded the technical development of football and even football components. Considering these factors, it can be said that such a research seems necessary and designing an appropriate model in the field of transfers of football players of Premier League, can be an important step in this direction.

Therefore, the most important reasons for the need for the present study include:

- Uncertainty of value components of professional football players in Iran

- Emphasis on pricing factors from external resources

- Unclear characteristics of each of the positions of goalkeeper, defender, midfielder and striker

- Lack of a specific scientific resource to refer to it in estimating the price of professional players

While during 2018 and 2019, we have witnessed a significant increase in the contracts of Iranian professional football league players, and on the other hand, the decrease in the club's revenues has also led to a significant downward trend, and the resources of revenue for the clubs, much of which must come from environmental advertising as well as television broadcasting rights have faced many challenges, these challenges make researchers to use scientific research to make the necessary predictions about the factors influencing the market and transfers, as well as determining the market value of football players in determine the Iranian Professional League using the databased quality model and use the possible results to create a positive impact on the rationality of receiving these wages and realizing their maximum value in the transfer market.

Therefore, efforts to create models and solutions based on scientific research in Iranian football to prevent the loss of these budgets and to organize the market value of the players of the Iranian Professional Football League, which includes a large part of the budgets of clubs and government companies supporting them, seems very necessary and vital. Accordingly, due to the lack of models and sufficient valuation expertise based on the reality of the football players market in all transfer seasons, we see that the existing vacuum leads to misuse by transfer intermediaries and other factors involved in this market and can be seen that these same people, with the approach that there is not enough knowledge in the field of pricing and determining the market value of professional league football players, can be considered the main and influential factors in creating unrealistic and false prices. Therefore, recognizing the factors affecting the valuation of professional football players in the Iranian Premier League will facilitate the transfer of Iranian Premier League players in order to earn more money and save the financial resources of clubs. The lack of a codified policy that can determine the value of players based on specific indicators is one of the major problems that the Premier League clubs have faced with. Therefore, designing a model from the perspective of football experts can solve the mentioned problems to some extent by determining the components affecting the evaluation of Iranian Premier League football players. Therefore, the researcher seeks to answer the question that what are the components of the market value model of Iranian Premier League football players? 


\section{Methodology}

The present study, because we seek to discover new concepts, from the perspective of nature, is exploratory - fundamental, from the perspective of approach is inductive, from the perspective of paradigm is interpretive - constructive paradigm, from the perspective of strategy is data-based theory with a constructivist approach, from the perspective of data collection is field and library data collection, from the perspective of goal is model presentation, and from the perspective of data collection tools is in-depth interviews and theoretical studies. Data-based theory is a qualitative method strategy that emphasizes on induction with the emergence of information from data, in order to create a theory with a model. In this study, after studying and reviewing the mentioned challenge in order to present a systematic and schematic model of the findings from the coded data, an attempt was made to use the constructivist approach in the data-based theory presented by Charms. Constructivist theory leads researchers to focus on what is happening in research, reiterating that researchers are a part of being and shall be flexible and follow empirical events. The epistemological view of the constructivist approach points out that this method does not claim to discover one and only one absolute reality, but instead believes in discovering a copy of reality that results from the interaction of the researcher and the data (Charmaz \& Mitchell, 2019). Using this method, the researcher can extract commonalities from a large amount of data and theorize in his / her research field based on it. This strategy uses a kind of inductive approach. That is, the process of theory formation in this strategy is the movement from part to whole. The main purpose of this method is to explain a phenomenon by identifying the key elements (concepts, categories and propositions) of that phenomenon and then classifying the relationships of these elements within the context and process of that phenomenon. The production of concepts, categories, and propositions is also a repetitive cyclical process. Overlapping processes in structural data-based theory analysis include: primary coding, centralized coding, axial coding, and theoretical coding (King \& Snowden, 2020).

Research participants included professors and professional football experts and all individuals with experience in the field of football club management. According to the characteristics and indicators specified in the inclusion criteria section, in order to perform sampling for in-depth interviews, purposeful sampling method and snowball sampling technique were used. After 25 interviews were conducted individually, each lasting approximately 30 minutes to an hour, while 20 articles were reviewed, and this process continued until theoretical saturation. In the source of data collection, due to the novelty of the research and the lack of possible limitations of the data, the triangulation approach (through the source method and method) was used and from various resources, including in-depth interviews; related articles; documents were used to obtain the required data.

Measurement tools included in-depth telephone interviews, in-person and through WhatsApp; field research; articles related to the value of professional football players in the Iranian Premier League. To analyze the data, the researcher reviewed and 
analyzed the qualitative data that collected the variables and the main concepts in the categories as well as the relationship between these variables and presented it as a model. Four strategies were used to audit the present study; initially, for reliability, the researcher coded again one of the interviews after one month and the results were compared with the Scott coefficient. It should be noted that for reliability and transferability, the research members' analysis method was used. In this method, the researcher's report was studied and examined in terms of accuracy and completeness. In this regard, reliability means whether if someone else coded the same findings were also made. In the present study, the "member review" method (interviewees) was used to confirm the validity of the study.

\section{Findings}

Table 1: Scope and number of resources for coding

\begin{tabular}{|l|c|}
\hline Resource & Number \\
\hline Interviews with senior managers of professional clubs & 7 people \\
\hline Interviews with experienced university professors with professional football management & 13 people \\
\hline Interviews with professional football experts and coaches & 5 people \\
\hline Literature and theoretical foundations, documents & 20 papers \\
\hline
\end{tabular}

Based on the information in Table 1, the characteristics of the participants in the interviews are given along with the number of articles used to extract meaningful concepts.

Table 2: Initial coding and conceptualization

\begin{tabular}{|c|c|}
\hline \multicolumn{2}{|l|}{ Initial coding } \\
\hline Initial statements and tagging & Initial concepts \\
\hline $\begin{array}{l}\text { Introducing the player based on personality criteria } \\
\text { The player's personality has an effect on strengthening his character. } \\
\text { Player personality is the basis for inclusive communication. } \\
\text { Positive personality traits lead to self-branding. }\end{array}$ & Player as a person \\
\hline $\begin{array}{l}\text { Introducing the player as a product } \\
\text { Introducing the player as a need } \\
\text { It is very important for customers to remember a product (player). } \\
\text { The customer is trying to get a specific product. } \\
\text { Player characteristics shown in the form of a product characteristics. }\end{array}$ & Player as a product \\
\hline $\begin{array}{l}\text { The player in the customer's mind is a symbol. } \\
\text { The role of symbols that focus on customers' positive perceptions of } \\
\text { the player. } \\
\text { Visual imaginations } \\
\text { Some players show the ability to become a symbol. }\end{array}$ & Player as a symbol \\
\hline $\begin{array}{l}\text { Special behavior of players } \\
\text { Unique associations } \\
\text { Geographical affiliation } \\
\text { A player fan community } \\
\text { Fanatic and various player fan pages }\end{array}$ & Being unique \\
\hline
\end{tabular}




\begin{tabular}{|c|c|}
\hline $\begin{array}{l}\text { Qualitative characteristics of a player } \\
\text { Strong communication with the media } \\
\text { Powerful planning manager }\end{array}$ & Being powerful \\
\hline $\begin{array}{l}\text { Being known for being a fan of clubs that have been around in the } \\
\text { past. } \\
\text { Ability to play with both feet professionally } \\
\text { Having acceptance among teammates } \\
\text { High ability to lead teammates and side posts and teammates in } \\
\text { general }\end{array}$ & Individual factors \\
\hline $\begin{array}{l}\text { Tactics in all situations } \\
\text { Fantastic technique and use it to increase team efficiency } \\
\text { Very high impact of the player on the results }\end{array}$ & Effectiveness and efficiency \\
\hline $\begin{array}{l}\text { Government and state media } \\
\text { Independent media } \\
\text { Popular media } \\
\text { Online media } \\
\text { Number of followers on social media }\end{array}$ & Media \\
\hline $\begin{array}{l}\text { Football Federation instructions } \\
\text { League organization rules } \\
\text { Club internal rules } \\
\text { Forming a players' union } \\
\text { AFC rules and regulations } \\
\text { FIFA rules and regulations } \\
\end{array}$ & Football institutions \\
\hline $\begin{array}{l}\text { Macro government policies } \\
\text { Sports and youth sports activities } \\
\text { Special approvals of the parliament and influential institutions } \\
\text { Broadcasting and produced content and inviting football players }\end{array}$ & Government institutions \\
\hline $\begin{array}{l}\text { Transparency of information flow } \\
\text { Amendments of the Articles of Association } \\
\text { Independence of the players' union } \\
\text { Club brand protection system } \\
\text { Improving Iran's business environment } \\
\text { Merit of football management }\end{array}$ & Consequences \\
\hline $\begin{array}{l}\text { Attending official national games } \\
\text { Attending national preparatory games } \\
\text { Attending national camps } \\
\text { Satisfaction of the coach at the time of the national team with the } \\
\text { performance of the player and constant invitation from him }\end{array}$ & $\begin{array}{l}\text { Number of national games in } \\
\text { the last season }\end{array}$ \\
\hline $\begin{array}{l}\text { Winning the provincial title of the best, in the position of the desired } \\
\text { player } \\
\text { Winning the national title of the best, in the position of the desired } \\
\text { player } \\
\text { Choice in media polls }\end{array}$ & Individual awards \\
\hline $\begin{array}{l}\text { Winning the championship with the current team in the Premier } \\
\text { League } \\
\text { Winning the FA Cup } \\
\text { Attending the higher stages of the Asian Champions League } \\
\text { Number of past championships in the teams in which the player has } \\
\text { played }\end{array}$ & Team Awards \\
\hline
\end{tabular}




\begin{tabular}{|c|c|}
\hline $\begin{array}{l}\text { Tall players are usually the focus of more coaches } \\
\text { The height of the players affects their price due to their position }\end{array}$ & $\begin{array}{l}\text { The player's height relative } \\
\text { to the position }\end{array}$ \\
\hline $\begin{array}{l}\text { Number of games played as a player in the starting lineup last season } \\
\text { Attending as a substitution in team games } \\
\text { Reasons for not attending games }\end{array}$ & $\begin{array}{l}\text { Number of games in the last } \\
\text { season }\end{array}$ \\
\hline $\begin{array}{l}\text { The global price of goalkeepers is slightly lower than other positions } \\
\text { Number of foreign goalkeepers in the league and current currency } \\
\text { prices } \\
\text { Use the young goalkeepers of the club academy } \\
\text { Number of received goals in the last season } \\
\text { Number of clean sheets in the last season }\end{array}$ & Goalkeeper position \\
\hline $\begin{array}{l}\text { Low number of defenders during the league } \\
\text { The physical strength of a defender } \\
\text { Ability to play making from the defensive line } \\
\text { Number of cards and fines in the last season }\end{array}$ & Defender position \\
\hline $\begin{array}{l}\text { Number of assists and goals scored } \\
\text { The amount of impact on the team and the game } \\
\text { Maintaining a very high and stable level of readiness }\end{array}$ & Midfielder position \\
\hline $\begin{array}{l}\text { Number of goals scored in all games of a season } \\
\text { Number of missed opportunities with a high percentage of goal } \\
\text { probability } \\
\text { High impact even in short presence } \\
\text { Be a goal scorer by nature }\end{array}$ & Striker position \\
\hline $\begin{array}{l}\text { Injury rate in the last season } \\
\text { Number of games lost during the season due to the injury } \\
\text { History of player injuries in the past }\end{array}$ & Foot condition \\
\hline $\begin{array}{l}\text { The minutes on the field } \\
\text { Compare the number of minutes on the field with the maximum time }\end{array}$ & Minutes of the game \\
\hline $\begin{array}{l}\text { Reasons for not being on the ground for many minutes } \\
\text { Ratio of goals scored per minute on the field } \\
\text { The ratio of goals scored to the number of games }\end{array}$ & Goal ratio \\
\hline $\begin{array}{l}\text { One of the main factors in pricing players on reputable websites is age. } \\
\text { Younger players price are more than players over } 30 \text { years old. }\end{array}$ & Player age \\
\hline $\begin{array}{l}\text { Usually, players who are in positions close to the opponent's goal have } \\
\text { a higher price } \\
\text { The number of goals scored plays a big role in the price of the player }\end{array}$ & Player position \\
\hline $\begin{array}{l}\text { The right of imaging and advertise and sell the player's shirt } \\
\text { Amount of offers received for the player } \\
\text { Popularity and acceptance of a player among the media and fans } \\
\text { Being on the bench or playing fixed in games and the impact they have } \\
\text { on the media }\end{array}$ & $\begin{array}{l}\text { Commercial income and } \\
\text { amount of demand }\end{array}$ \\
\hline $\begin{array}{l}\text { The exact amount of the previous years' contract } \\
\text { The desired amount of clubs } \\
\text { The amount desired by the players }\end{array}$ & $\begin{array}{l}\text { Numerical value of the } \\
\text { contract }\end{array}$ \\
\hline $\begin{array}{l}\text { Player price range in the transfer season } \\
\text { The final budget of a club in a season }\end{array}$ & End of each sports season \\
\hline $\begin{array}{l}\text { The maximum price that is affordable for the club } \\
\text { The agreed price of the club and the player }\end{array}$ & The final price \\
\hline Final registration of the contract in the football board & $\begin{array}{l}\text { Final registration of the } \\
\text { contract }\end{array}$ \\
\hline
\end{tabular}


Agreement between the parties and the clauses requested by the customer and the player

Record all options and the parties agree on the price of each option

Based on the findings of Table 1, in the initial coding, pieces of data such as lines, words, segments and events are examined. In particular, we consider them from an analytical point of view. In fact, the initial codes are placed in a combination and based on the content of each of them in the concepts or categories. The purpose of initial coding is to break down the collected data set into the smallest possible conceptual components. At this step of the research, out of about 220 sentences implemented from the interviews, after removing duplicate and unrelated items, about 109 initial codes were identified and marked by the researcher in the first step. In the next step, similar phenomena must be classified with each other, otherwise we will be caught between a large numbers of primary codes. Once we have identified a specific phenomenon in the data, then we can classify the data. The process of classifying primary code that appears to be related to similar phenomena is called conceptualization. At this step, the obtained initial codes were classified into 30 basic concepts, based on the procedures presented in Table 2 .

Table 3: Categorization and centralized codes

\begin{tabular}{|l|l|l|}
\hline Initial concepts & Categories & Centralized coding \\
\hline $\begin{array}{l}\text { Player as a person } \\
\text { Player as a product }\end{array}$ & Positioning & Special value \\
\hline $\begin{array}{l}\text { Being unique } \\
\text { Being powerful } \\
\text { Individual factors } \\
\text { Effectiveness and efficiency }\end{array}$ & Player image & \\
\hline $\begin{array}{l}\text { Media } \\
\text { Football institutions } \\
\text { Government institutions } \\
\text { Consequences }\end{array}$ & & \\
\hline $\begin{array}{l}\text { Number of national games in the last } \\
\text { season }\end{array}$ & Institutions and consequences & Requirements \\
Personal awards & & \\
Team awards & & \\
Player height & & \\
Number of games in the last season & & \\
Goalkeeper position & & \\
Defender position & & \\
Midfielder position & & \\
Striker position & & \\
Foot condition & & \\
Minutes of the game & & \\
Goal ratio & & \\
\hline $\begin{array}{l}\text { Player age } \\
\text { Player position }\end{array}$ & & \\
\hline
\end{tabular}


PLAYERS IN IRAN: A CONSTRUCTIONIST APPROACH OF GROUNDED THEORY

\begin{tabular}{|l|l|l|}
\hline \hline $\begin{array}{l}\text { Commercial income and amount of } \\
\text { demand }\end{array}$ & & \\
\hline $\begin{array}{l}\text { Numerical value of the contract } \\
\text { End of each sports season }\end{array}$ & Market value & Market value of a player \\
\hline $\begin{array}{l}\text { The final price } \\
\text { Registration of the contract }\end{array}$ & Final value & \\
\hline
\end{tabular}

After categorizing the concepts, they should be centralized, which is called centralized coding. In centralized coding, one must constantly oscillate and move between two types of inductive and deductive thinking. At this step of the research, finally 3 centralized codes were presented. Centralized categorization and coding are presented in Table 3.

Table 4: Sub-categories and main categories of presenting the market value model of Iranian football players

\begin{tabular}{|l|c|}
\hline Sub-categories & Main categories \\
\hline Positioning - Player image & Special value \\
\hline Institutions and consequences - Prerequisites - Transfer market factors & Requirements \\
\hline Market value - Final value & Market value of a player \\
\hline
\end{tabular}

The process of classifying concepts that seem to be related to similar phenomena is called categorization. We then give the category that includes the phenomenon a conceptual name, but it should be noted that this name must be more abstract than the names of the concepts that make up the category. At this step, 7 categories were identified. The subcategories and main categories of the model of presenting the market value model of Iranian Premier League football players are presented in Table 4.

The present study, at the highest level of reduction, reduced the categories of construction to three general categories of equity, requirements and market value of a player, which in the most desirable way, integrated the concepts created in the research into three levels. The final price or value of a football player in the Iranian Premier League in the transfer market is determined based on the specific values of that player and a series of requirements. Finally, the final research model was presented in Figure (1). As shown in this figure, prerequisites were selected as the central category of the research, which includes the main factors of valuation of a football player and reflects the main concerns of the participants. 


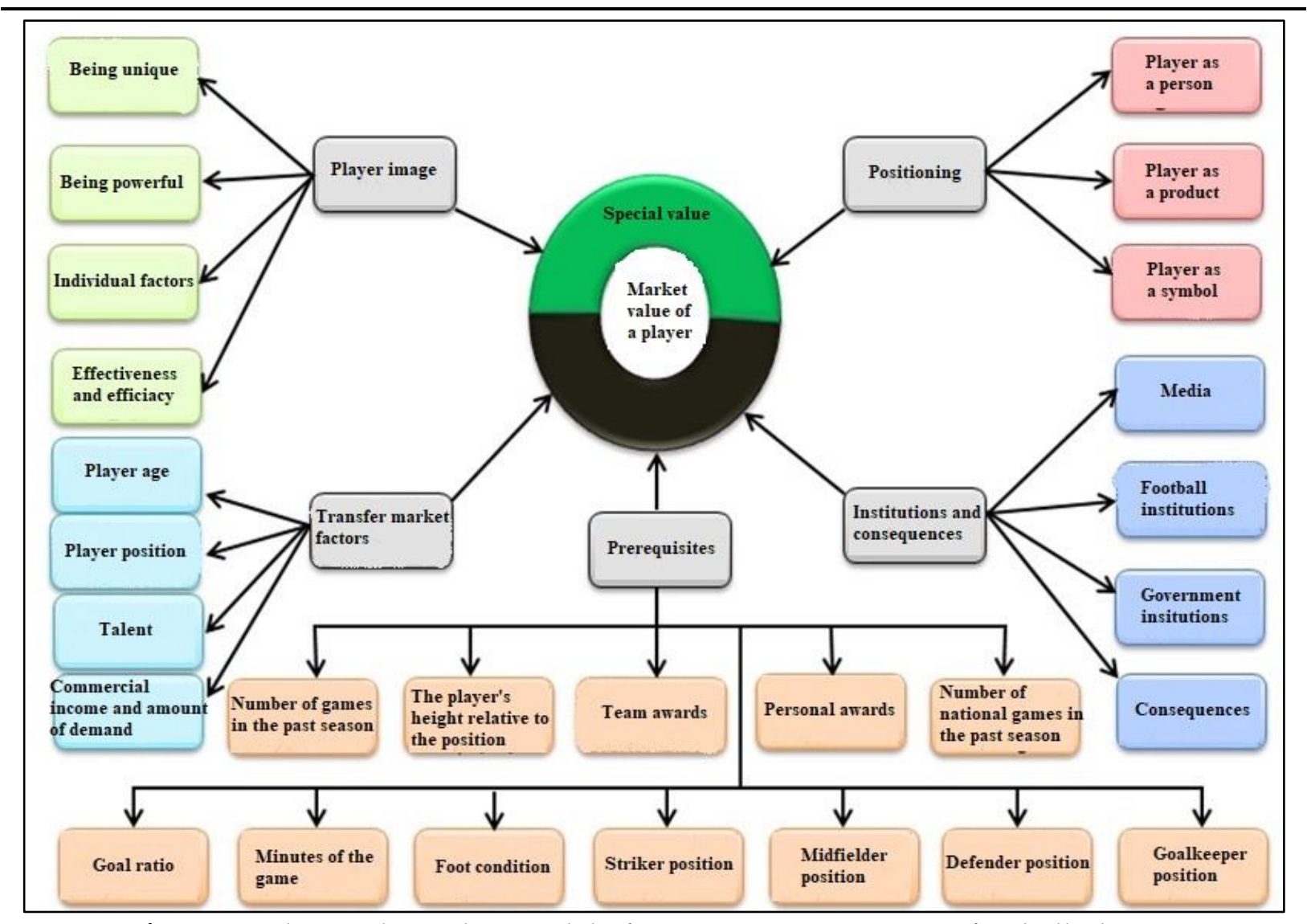

Figure 1: The market value model of Iranian Premier League football players

\section{Discussion and conclusion}

In order to achieve the effective components on the value of Iranian professional football players, introducing the player based on personality criteria, the player's personality has an effect on strengthening his personality. The player's personality is the basis for inclusive communication. Positive personality traits lead to self-branding. Finally, it was obtained as the main components of the player in a person category. While introducing the player as a product, introducing the player as a need, is very important for customers to remember a player. The customer tries to get a specific product, and finally the characteristics of the player are shown in the form of the characteristics of a product. It was considered as the most important component of the player as a product. The player is a symbol in the customer's mind. Symbols that focus on customers' positive perceptions of the player play an important role. Visual and metaphorical representations of the players and while some players show the ability to be symbolic were obtained as components of the player as a symbol. The specific behavior of the players, the uniqueness of the associations, the geographical affiliation, the fan community of a player and the fanatical and diverse fan pages of the player were obtained as a component of uniqueness.

The quality characteristics of a player, strong communication with the media and a powerful program manager were considered as components of being strong. Being 
famous for prejudice against clubs that have been in the past, the ability to play with both feet professionally, having acceptance among teammates and the high ability to lead teammates and side posts and in general teammates as individual factors determine the special value of the player. Tactics in all situations, excellent technique and its use to increase the efficiency of the team and the very high impact of the player in the results obtained under the heading of effectiveness and efficiency of the player is effective in determining its seniority. Government and state media, independent media, popular media, online media and the number of followers on social media are very important factors in determining the price of a player. Izdiar et al. (2015) in a study in this field concluded that what is important in Iranian football to determine the price of players is the position of social acceptance, club brand and variables that during the study were named as elements and influencing factors has been encountered.

The rules of the Football Federation, the rules of the league organization, the internal rules of the clubs, the formation of the players' union, the rules and regulations of the AFC, the rules and regulations of FIFA were considered as football institutions determining the value of the player. The macro-policies of the government, the actions of ministry of sports and youth, special approvals of the parliament and influential institutions, and the radio and television and the produced content and the invitation of football players were considered as components of the governing institutions. Transparency of information flow, amendment of articles of association, independence of the players' union, protection system of club brands, improvement of Iran's business environment and meritocracy of football management were considered as consequences of the value of Iranian professional football players.

Attending official national games, national preparation games, national camps, national team coach's satisfaction with the player's performance and constantly inviting him as components of the number of national games last season are effective in determining the value of players. Other factors such as the number of national games, the number of goals scored, the level of the player's previous team and the number of games in the previous season are also among the factors influencing the pricing of players. The presence of players at the levels of national teams, including teenagers, youth, Omid and adults, which in this study focused on all these categories, seems to show a large extent the ability and competence of the player and the player who was able to reach this position, has more capabilities than other players; Also, the ability to score and the number of goals scored by the player can be considered as one of the factors affecting the price of the players. Of course, players in different positions of the game have different performance in scoring, so that the attacking conditions for scoring are much more favorable than the defender and the striker is expected to have more goals scored during the season, but the players of other positions, if they score, have a much higher value than the player without scoring in the same position, and in a way, scoring creates value for the player.

Winning a local and national title in the position of the player in question, the choice in the media polls is a component of individual awards. Winning the 
championship with the present team in the Premier League, winning the FA Cup, participating in the higher stages of the Asian Champions League and the number of previous championships in the teams in which the player has participated are team awards. The number of games played as a player in the main squad last season affects the price of the player. The presence as a substitution in team games. The reasons for not attending the games are indicators of the number of games last season.

The world price of goalkeepers is slightly lower than other positions. The number of foreign goalkeepers in the league and the current exchange rate, the use of young goalkeepers in the club academy, the number of goals scored last season and the number of clean sheets in last season is effective in determining the price of goalkeeper. The small number of defenders during the league, the high physical strength of a defender, the ability to play from the defensive line, the number of cards and penalties in the last season are decisive in determining the value of the defensive position. The number of assists and goals scored, the amount of impact on the team and the game, and maintaining a very high and stable level of preparation are effective in determining the value of the midfielder's position. The number of goals scored in all games of a season, the number of missed opportunities with a high percentage of goal probability, high impact even in the presence of a short and inherently goal-scoring are effective in determining the value of the striker position.

The number of injuries in the last season, the number of games lost during the season due to injury, and the player's history of injuries in the past were considered as the foot condition. The number of minutes on the field, comparing the number of minutes on the field with the maximum time that the player could be on the field, are the reasons for not having many minutes on the field as components of the minutes of the game. Jarsat Shamsabadi (2010) in a part of his model has examined the relationship between players' performance data with team win percentage, which includes players' performance data as mentioned above.

One of the main factors in player pricing on reputable websites is age, the price of players younger than players older than 30 is considered as a component of player age. Abdi et al. (2015) in a similar study determined the role of influential factors in determining the price of football players. This part of the achievements of the present model is in line with the findings of previous researchers. Parker et al. (2008) cited experience and personal characteristics as factors influencing player evaluation. It seems that, perhaps, when the age of the player increases, his experience will increase also or the younger player as he played many games in the younger age groups may gain a good experience that can be consistent with the present study. Depken and Rajaskhar (2010) also stated age as one of the players' valuation factors, which is consistent with the present study. Hey (2015) considered age as one of the factors in data collection to determine the market value of players. Market value refers to the fact that in the market of buying and selling football players, the price placed on each player is considered as the market value of that player. Important factors play a role in determining the market value of a football player, and perhaps one of the most important is the age of the player. 
Well-known clubs around the world today have policies in place to attract young players, so that these clubs identify talented youth and very young players, by attracting and empowering them for many years, so that the club benefits from the existence of those players. Usually, taller players are more important to the coaches. The height of the players is proportional to their position, which affects their price. The components of the player's height were considered.

Usually, players who are in positions close to the opponent's goal have a higher price and the number of goals scored plays a big role in the price of the player that was considered as a component of the player's position. The ratio of goals scored per minute on the field, the ratio of goals scored to the number of games was considered the ratio of goals. Hey (2013) stated factors such as the level of the player's previous team in which he played and also the number of goals scored by the player as part of the player's performance information and used them to predict the value of the players, which is consistent with the present study. The level of the player's previous team is also considered as another factor influencing the player's price. It seems that a player who plays in high-level and well-known teams has a higher price than the player of low-level teams and lower categories. The number of games in the previous season, in a way, can show the key and competence of the player. Surely the clubs will use players during the season who can have the best performance for their team and male the club and its team towards the goals of pre-designed plans, otherwise the teammates will take the place of that player in the starting lineup. The right to image and advertise and sell a player's shirt, the amount of offers received for a player, the popularity and acceptance of a player among the media and fans, being on the bench or playing fixed in a game and the influence they have on the media are considered as components of business income and the amount of demand. The contract amount of previous years is the amount desired by the clubs, the amount desired by the players as components of the numerical value of the contract. The suffering of player prices in the transfer season and the final budget of a club in a season are the components of the end of any sporting season. The maximum price that is affordable for the club and the price agreed between the customer and the player are as components of the final price of the contract registration in the football board, and the agreement between the two parties and the clauses requested by the customer and the player and the registration of all options and the agreement of the parties for the price of every option are considered as the final registration components of the contract.

In general, it can be acknowledged that prerequisites were selected as the central category of the research, which includes the main evaluation factors of a football player and reflects the main concerns of the participants. The market value of a player in the Iranian Football Premier League is determined by the position and image of that player in the form of the specific value of that player and by the requirements that include institutions and consequences, prerequisites and transfer market factors. Therefore, it is suggested that the most important requirements for the value of professional football players, the price on the transfer market site, the prerequisites and institutions and the 
consequences for valuing a player be considered by the club managers. The steering committee for the selection of players should be included in the administrative structure of the clubs based on the proposed indicators in Iranian professional clubs. A workshop on institutionalizing the characteristics of the present study for managers and coaches of professional clubs should be held by the league organization. The numerical value of the contract at the end of each sports season, the final price of the contract, the market value, shall be considered as the final market value of a player. Optional contracts should be on the agenda of managers appropriate to the capacity of the players. Components of each of the categories of position making - player image; institutions and consequences prerequisites - transfer market factors - market value - final value - most important categories in determining the market value of professional football players in the Iranian Premier League should be the basis of legal contracts with players.

\title{
Conflict of Interest Statement
}

The authors declare no conflicts of interests.

\begin{abstract}
About the Authors
Rasool Nazar, Strategic management specialist in sports, Faculty member of university $\&$ associate professor of sports management, consultant in the affairs of professional football clubs.
\end{abstract}

Saeid Azari, Professional management specialist in football, CEO of Khuzestan Steel Sports Club.

\section{References}

Abdi Sh, Zangiabadi M., Talibpour M. (2015). Determining the role of factors affecting the evaluation of Iranian Premier League players. Journal of Human Resource Management in Sports, 3 (2), 121-136.

Amir E., Livne G. (2005). Accounting, valuation and duration of football player contract. Journal of Business finance and Accounting, 32 (3-4) PP549-586

Arab Nermi, Bita; Goodarzi, Mahmoud; Sajjadi, Seyed Nasrollah; Khabiri, Mohammad (2018). Analysis of the status of professional sports in Iranian national television, Studies of Sports Management, No. 47, pp. 37-17. (Persian)

Bagheri M., Namian M., Khodamradi S, Ghorbani M (2011). Evaluation and selection of Premier League football players based on financial and sports indicators, Journal of Accounting and Financial Management, Special Issue of Research Week,1(1) pp. (50-65).

Bondarik, R., Pilatti, L. A., \& Horst, D. J. (2020). Sports mega-events and overestimated promises: the case of the 2014 FIFA World Cup in Brazil. Journal of Tourism and Cultural Change, 1-17. 
Baena V. (2016). Global marketing strategy in professional sports. Lessons from FC Bayern Munich. Journal Soccer \& Society. (30)2, 1-15.

Charmaz K. (2019). With constructivist grounded theory you can't hide: Social justice research and critical inquiry in the public sphere. Qualitative Inquiry, 26 (2): 165176.

Chan, Michael (2014). Factors to determine a football player's transfer Value-comparison to US Sport" Arsenal review, N.P.,n.d. Web. 1 May •

Depken C. A. and Rajasekhar R. (2010). Open Market valuation of Player Performance in Cricket: Evidence from the Indian Premier League. Available at SSRN 1593196121.

Espriella R. L., Restrepo C. G. (2020). Research methodology and critical reading of studies grounded theory Teoría fundamentada. Revista Colombiana de Psiquiatría (English ed.), Available online 18 April 2020, In Press, Corrected Proof.

He, M. (2015). Exploring the Relationship Between Football Player's Performance and Their Market Value. Masters Thesis, Leiden Institute of Advanced Computer Science (LIACS). 1-85

He, Y. (2013). Predicting Market Value of Soccer Players Using Modeling Techniques. Berkeley.edu.1-15

Izdiar M., Memari J., Mousavi M. (2015). The equation of pricing of Iranian Premier League players, Journal of Economic Research 51(1), pp (25-40).

Jarsat Shamsabadi P. (2010). Valuation of professional football players based on their performance, using the capital asset pricing model (CAPM). Master Thesis in Financial Management, Faculty of Administrative Sciences and Economics, University of Isfahan. P 125

King E. L., Snowden D. L. (2020). Serving on multiple fronts: A grounded theory model of complex decision-making in military mental health care. Social Science \& Medicine, 250: 342-358.

Nazari, Rasool; Hajlou, Ali Amir; Azimzadeh, Seyed Morteza (2019). Comprehensive identification of the excellence model of Iran's national football brand, new approaches in sports management, 7(24), pp. 109-95. (Persian)

Parker D., Burns P. and Natarajan H. (2008). Player Valuations in the Indian Premier League. Frontier Economics, 116, 1-17.

Origi, Anthony Onyango; Jared Deya (2019). Strategic Drivers of Sport Commercialization in Kenya: A Survey of Football Subsector, International Journal of Academic Research in Business and Social Sciences. 9(9): 1-19

Rezaei Sufi, Morteza; Farahani, Abolfazl; Shabani, Abbas (2017). Analysis of professional sport environment, Applied Research in Sport Management, 1(6): 118-107. (Persian)

Rezaei, Shamsuddin (2016). Sports Economics, Leisure and Tourism, First Edition, Ilam Publications: pp. 89-65. (Persian) 
Sadeghi, Hossein; Asgharpour, Hossein; Golchinfar, Nazli (2009). Estimation of the demand function of watching the Iranian Football Premier League, Quarterly Journal of Economic Research, (3), pp.41-27. (Persian)

Xu, J., \& Yang, R. (2019). Sports industry agglomeration and green economic growthEmpirical research based on panel data of 30 provinces and cities in China. Sustainability, 11(19), 5399.

Yang, S., Xu, J., \& Yang, R. (2020). Research on coordination and driving factors of sports industry and regional sustainable development-Empirical research based on panel data of provinces and cities in eastern China. Sustainability, 12(3), 813.

Yiapanas, G., Thrassou, A., \& Vrontis, D. (2020). An Integrated, Multi-Agency, Consumer-focused, Safety Management Approach in the Sports Industry. In Handbook of Research on Contemporary Consumerism (pp. 222-241). IGI Global. 
Creative Commons licensing terms

Authors will retain the copyright of their published articles agreeing that a Creative Commons Attribution 4.0 International License (CC BY 4.0) terms will be applied to their work. Under the terms of this license, no permission is required from the author(s) or publisher for members of the community to copy, distribute, transmit or adapt the article content, providing a proper, prominent and unambiguous attribution to the authors in a manner that makes clear that the materials are being reused under permission of a Creative Commons License. Views, opinions and conclusions expressed in this research article are views, opinions and conclusions of the author(s). Open Access Publishing Group and European Journal of Physical Education and Sport Science shall not be responsible or answerable for any loss, damage or liability caused in relation to/arising out of conflict of interests, copyright violations and inappropriate or inaccurate use of any kind content related or integrated on the research work. All the published works are meeting the Open Access Publishing requirements and can be freely accessed, shared, modified, distributed and used in educational, commercial and non-commercial purposes under a Creative Commons attribution 4.0 International License (CC BY 4.0). 